\title{
Phytochemical Screening and GC-MS Chemical Profiling of Ethyl Acetate Extract of Seed and Stem of Anethum sowa Linn.
}

\author{
Muhammad Abdullah Al-Mansur ${ }^{1}$, M. Mahboob Ali Siddiqi' ${ }^{2}$, Md. Ahedul Akbor ${ }^{1}$ \\ and Koushik Saha ${ }^{3}$
}

\author{
${ }^{1}$ Institute of National Analytical Research and Services (INARS), BCSIR, Dhaka-1205, Bangladesh \\ ${ }^{2}$ Institute of Natural Sciences, United International University, Dhaka-1209, Bangladesh \\ ${ }^{3}$ Department of Chemistry, Jahangirnagar University, Savar, Dhaka-1342, Bangladesh
}

(Received: September 20, 2017; Accepted: October 28, 2017; Published (web): December 23, 2017)

\begin{abstract}
Tahe phytochemical constituents from the ethyl acetate extracts of seed and stem of Anethum sowa were identified by qualitative and gas chromatography-mass spectroscopy (GC-MS). Qualitative analyses exhibited the presence of alkaloids, flavonoids, tannins, carbohydrate, steroids and terpenoids in both extracts. In GC-MS analysis of A. sowa 6 notable peaks (3,4,4a,5,6,7,8,9-Octahydro-2H-benzocyclohepten-2-one, 2,2,4,6,7-Pentamethyl1,2,3,4-tetrahydro quinoline, 5-Ethyl-2-methyl-pyridin-4-amine, 2-(2-Furyl) pyridine, 9-Ethyl 9-borabicyclo-[3.3.1]nonane and 7-Methylenebicyclo-[4.2.0]-octane) and 5 significant peaks (3-Cyclopentyl-1-propyne, 2,2,4,6,7Pentamethyl-1,2,3,4-tetrahydroquinoline,3,4,4a,5,6,7,8,9-Octahydro-2H-benzocyclohepten-2-one, 1,5-Naphthy-ridin2-amine and Octahydro-4,7-methano-5H-inden-5-one) with comparatively higher peak area (\%) among 26 and 23 compounds were detected from the ethyl acetate extract of stem and seed respectively. The study encapsulates the information regarding the phytochemical constituents present in the extracts which may have pharmacological importance.
\end{abstract}

Key words: Anethumsowa, gas chromatography-mass spectroscopy (GC-MS), ethyl acetate extract, phytochemical constituents.

\section{INTRODUCTION}

A greater portion of nature is covered with plant kingdom. Plants referred to medicinal plants are a significant segment of inherent medical systems all over the world due to the presence of important natural products. There have been augmented waves of fascination in the area of research in natural products chemistry. This phase can be ascribed to several considerations comprising unmet therapeutic needs, the stunning assortment of both chemical structures and biological activities of naturally occurring secondary metabolites, the utility of novel bioactive natural compounds as biochemical probes.

Correspondence to: Muhammad Abdullah Al-Mansur E-mail: nayeembcsir@gmail.com Tel: +88-01715010829

Dhaka Univ. J. Pharm. Sci. 16(2): 187-194, 2017 (December) the development of novel and sensitive techniques to detect biologically active natural products and improved techniques to isolate, purify and structurally characterize these active constituents. ${ }^{1}$ Our investigation is focused on the investigation onto phytochemical constituents in ethyl acetate extract of seed and stem of Anethum sowa using gas chromatography-mass spectroscopic (GC-MS) approach.

Anethum sowa Linn. (Common name- Dill; Bengali- Shulfa; Family-Apiaceae), an annual or a biennial cold weather glabrous and aromatic herb, reaches up to $1 \mathrm{~m}$ in height. In Bangladesh, it is abundantly cultivated in the northern part of the country and throughout India mainly in Punjab, Uttar Pradesh, Gujarat, Maharasshtra, Assam and West Bengal. It is often found with weed of cultivation and 
even as an escape in irrigated fields. Its seed has insecticidal, ovicidal and synergistic activity and is also known to contain of dillapiol and also contains essential oil having antioxidant and antimicrobial activity. $^{2}$

The aim of the present work was to phytochemically screen the plant metabolites present in the ethyl acetate extract of seed and stem qualitatively by applying phytochemical tests and quantitatively by gas chromatography-mass spectroscopic (GC-MS) analysis. In GC-MS analysis, the percent area represents the percentage wise amount of the respective compound.

\section{MATERIALS AND METHODS}

Plant collection, identification and authentification. Fresh stem and seed of $A$. sowa were collected from BCSIR campus, Dhaka and identified by the taxonomist of Bangladesh National Herbarium, Dhaka, where a voucher specimen $($ DACB No. $=31282)$ has been deposited. ${ }^{2}$

Extraction and processing. Freshly collected stem and seed of A. sowa were dried in open air and powdered by using a grinding machine. The air-dried and powdered material of seed $(250 \mathrm{~g})$ was soaked by ethyl acetate (2.5 litres $\times 3)$ at room temperature for 2 days against each soaking. Consequently gummy mass of ethyl acetate extract $(2.01 \mathrm{~g})$ was obtained from the filtrate using rotary evaporator under reduced pressure. By the same process, the air-dried and powdered material of stem $(250 \mathrm{~g})$ was soaked in ethyl acetate (2.5 litres $\times 3)$ at room temperature for 2 days for each soaking. Consequently, gummy mass of ethyl acetate extract (1.45 g) was separated by filtration followed by evaporation of solvent using rotary evaporator under reduced pressure. ${ }^{2}$ The ethyl acetate extracts of seed and stem were subjected to qualitative phytochemical screening and GC-MS analysis.

Chemical reagents for screening of phytochemical constituents. Chemicals and reagents like ethyl acetate, sulphuric acid, Mayer's reagent, Hager's reagent, Wagner's reagent, acetic anhydride, lead acetate, alcoholic solution of $\alpha$-napthol, ammonia solution, sodium chloride, gelatine solution, chloroform, Fehling's solution A and B, sodium hydroxide, hydrochloric acid, mercuric chloride, potassium iodide (KI) and benzene were used to analyze phytochemicals present in the ethyl acetate extract of seed and stem of A. sowa. All solvents were of analytical grade and collected from commercial sources (E. Merck (Germany), BDH (England) and Sigma Aldrich (Germany).

Methodology for screening of phytochemical constituents. Specific chemical tests were carried out for phytochemical constituents. Standard procedures were followed to identify the constituents as described by Harborne ${ }^{3}$, Trease and Evans ${ }^{4}$ and Sofwara $^{5}$ to confirm the presence of various constituents in the ethyl acetate extracts only.

Instrumentation for GC-MS analysis. The GCMS analysis was performed on a GC-MS-QP 2010 Ultra instrument equipped with $\mathrm{AB}$ innowax column $(30 \times 0.25 \mathrm{~mm}$ id, film thickness $0.25 \mu \mathrm{m})$. Initially, oven temperature was maintained at $120^{\circ} \mathrm{C}$ for 1 minute and temperature was gradually increased up to $270^{\circ} \mathrm{C}$ for 25 minutes and $0.5 \mu \mathrm{l}$ of sample was injected for analysis. Helium at $1.15 \mathrm{ml} / \mathrm{min}$ was the carrier gas. The sample injector and mass transfer line temperature were set at $200^{\circ} \mathrm{C}$ and $250^{\circ} \mathrm{C}$ and split ratio was 200 throughout the experiment periods. The ionization mass spectroscopic analysis was done with $70 \mathrm{eV}$. Mass spectra were recorded across the range of $50 \mathrm{~m} / \mathrm{z}$ to $650 \mathrm{~m} / \mathrm{z}$ for the duration of 40.75 minutes. Identification of components was based on comparison of their mass spectra with those of Wiley and NIST Libraries, Adams ${ }^{6}$ and by comparison of their retention indices with literature values. $^{7}$

\section{RESULTS AND DISCUSSION}

Analysis of phytochemical constituents. The phytochemical investigation of the ethyl acetate extract of seed and stem of $A$. sowa revealed the presence of carbohydrates, flavonoids, tannins, steroids, glycosides, alkaloids, anthraquinone, and terpenoids. On the contrary, only saponins are absent in extract of stem and seed. In addition, 
carbohydrates, flavonoids, tannins, alkaloids, steroids and terpenoids are present whereas glycosides, anthraquinone are absent in extract of stem.

From the previous study, it is evident that carbohydrates may possibly increase the potency of the therapeutically important ingredients. Hence, a finer curative result may be gained from the combination of active principles in each plant than by single isolated constituent. ${ }^{8,9}$ Additionally, tannins have antidiarrheal impact and these substances may precipitate proteins on the enterocytes reducing peristaltic movement and intestinal secretion. ${ }^{10}$ Furthermore, saponins have expectorant, cardiotonic and hypoglycemic activity. ${ }^{11-14}$ Besides, glycosides have laxative, diuretic and antiseptic properties. ${ }^{15-17}$ Moreover, flavonoids demonstrate significant antimicrobial $^{18}$, hypoglycemic and anti-diabetic, ${ }^{19}$ anti-inflammatory, ${ }^{20}$ antioxidant, ${ }^{21,22}$, anti-tumour ${ }^{23}$ and free radical-scavenging activities. From the phytochemical study it was revealed that the ethyl acetate extract of seed and stem may have antiinflammatory, antioxidant agents associated with free radical-scavenging action due to the presence of flavonoids and antidiarrheal activity owing to tannins. In addition, the presence of terpenoids indicates that the ethyl acetate extract may have cytotoxicity activity. ${ }^{24}$

Table 1. The phytochemical investigation of the powder and ethyl acetate extract of seed and stem of $A$. sowa.

\begin{tabular}{llcc}
\hline Chemical class of constituents & \multicolumn{1}{c}{ Test } & $\begin{array}{c}\text { Ethyl acetate } \\
\text { extract of seed }\end{array}$ & $\begin{array}{c}\text { Ethyl acetate extract } \\
\text { of stem }\end{array}$ \\
\hline Carbohydrates & Molisch's test & + & + \\
Flavonoids & a) Alkaline reagent test & + & + \\
& b) Lead acetate test & + & + \\
Tannins & a) Gelatin-salt block test & + & + \\
& b) Lead acetate test & + & + \\
Steroids & a) Salkowski test & + & + \\
& b) Liebermann-Burchard's test & + & - \\
Saponins & a) Frothing & - & - \\
Glycosides & b) Emulsification & - & - \\
Alkaloids & a) Sodium hydroxide reagent & - & + \\
& b) Test for glycosides with glucose as the glycone & + & + \\
Terpenoids & a) Mayer's reagents & + & + \\
Anthraquinone & b) Hager's test & + & + \\
\hline
\end{tabular}

+=present; - = absent.

GC-MS analysis of the extracts. In the GC-MS analyses of A. sowa, 26 compounds were identified from the ethyl acetate extract of stem and 23 compounds from that of seed. The recognition of phytochemicals is determined by the peak area, molecular weight and molecular formula. The chromatogram (Figure 1) of ethyl acetate extract of stem represents 6 notable peaks. Among these, 3,4, 4a,5,6,7,8,9-Octahydro 2H-benzocyclohepten-2-one with retention time 6.135 has the highest peak area $(17.098 \%)$. In addition, 2,2,4,6,7-Pentamethyl1,2,3,4-tetrahydro quinoline giving retention time 8.654 refers peak area $(10.51 \%)$ while 5-Ethyl-2methyl-pyridin-4-amine with retention time 10.328 exhibits peak area increased by $4.69 \%$ compared to 2,2,4,6,7-Pentamethyl-1,2,3,4-tetrahydro quinoline. Moreover 7-Methylenebicyclo-[4.2.0]-octane showed retention time 14.797 with peak area $8.302 \%$ which 
is almost equally found against 9-Ethyl-9borabicyclo-[3.3.1]-nonane with retention time 18.991. Lastly 2-(2-Furyl) pyridine reveals $11.408 \%$ peak area at retention time 24.2. The chemical structures of the most prevalent compounds of ethyl acetate extract of stem of $A$. sowa have been shown in table 3.

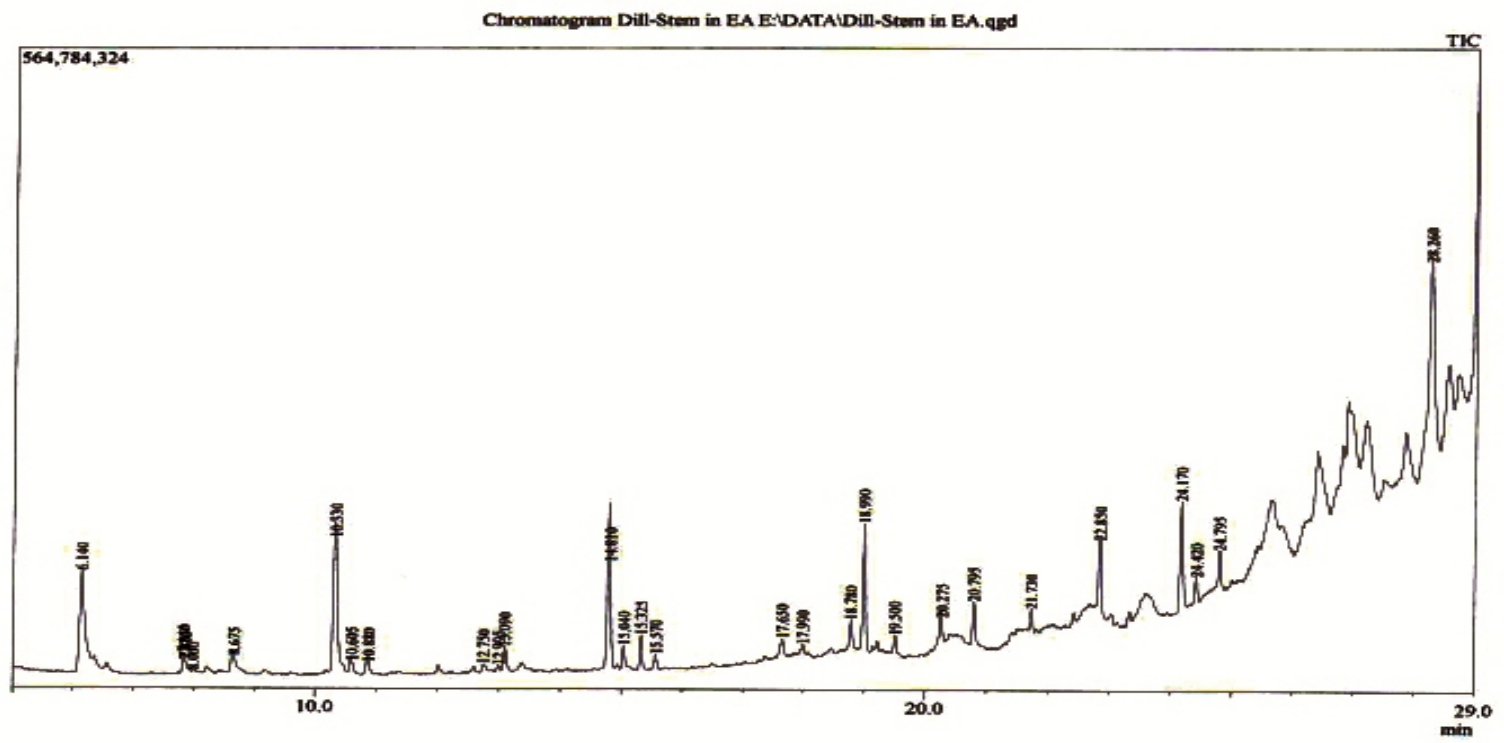

Figure 1. Chromatogram (GC/MS) of the ethyl acetate extract of stem of A. sowa.

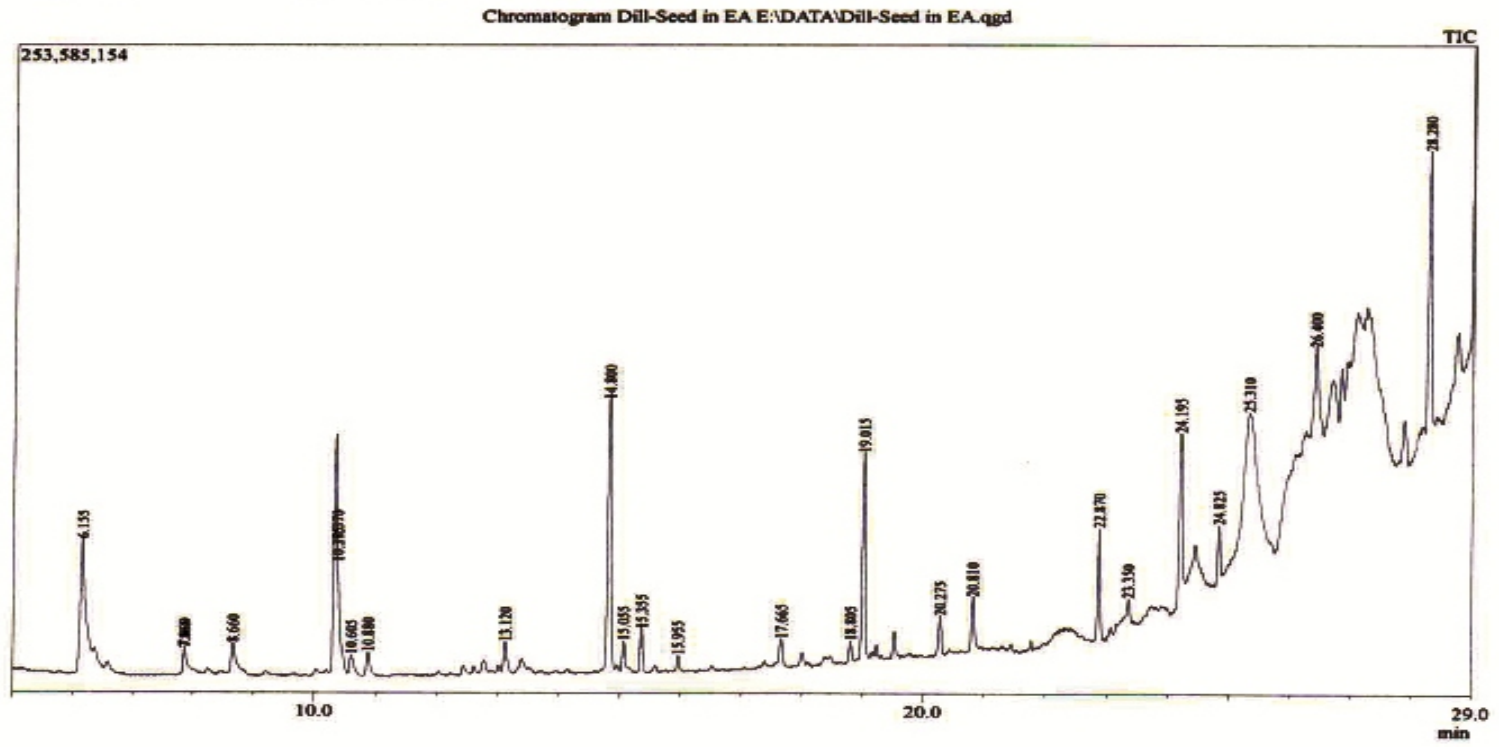

Figure 2. Chromatogram (GC/MS) of the ethyl acetate extract of seed of A. sowa.

From the GC-MS analyses of A. sowa, it is noticed that the ethyl acetate extract of seed provided 23 compounds. The chromatogram (Figure 2) of ethyl acetate extract of seed represents 5 significant peaks. Among them, 3-Cyclopentyl-1-propyne with retention time of 6.149 has peak area of $14.137 \%$. In addition, 2,2,4,6,7-Pentamethyl-1,2,3,4-tetra-hydro quinoline at retention time 8.668 refers peak area of $7.321 \%$ which was almost half of 3-Cyclopentyl-1propyne. Moreover 3,4,4a,5,6,7,8,9-Octahydro-H- 
benzocyclohepten -2-one with retention time 19.013 exhibited peak area $8.105 \%$ which is almost $1 \%$ higher than 1,5-Naphthyridin-2-amine. Furthermore Octahydro-4, 7-methano-5H-inden-5-one showed retention time of 25.296 with the highest peak area of
$24.673 \%$ among all compounds found in the ethyl acetate extract of seed of $A$. sowa. The chemical structures of the most prevalent compounds of ethyl acetate extract of seed of $A$. sowa have been shown in table 5 .

Table 2. Chemical constituents present in the ethyl acetate extract of stem as determined by GC-MS.

\begin{tabular}{|c|c|c|c|c|c|c|}
\hline No & Name of compound & Retention time & $\begin{array}{l}\text { Molecular } \\
\text { weight }\end{array}$ & $\begin{array}{l}\text { Molecular } \\
\text { formula }\end{array}$ & Peak area & $\begin{array}{l}\text { Peak area } \\
(\%)\end{array}$ \\
\hline 1 & $\begin{array}{l}\text { 2H-Benzocyclohepten-2-one, } \\
3,4,4 \mathrm{a}, 5,6,7,8,9 \text {-octahydro }\end{array}$ & 6.135 & 164 & $\mathrm{C}_{11} \mathrm{H}_{16} \mathrm{O}$ & 56785716 & 17.098 \\
\hline 2 & $\begin{array}{l}\text { Quinoline, 2,2,4,6,7-pentamethyl-1,2,3,4- } \\
\text { tetrahydro }\end{array}$ & 8.654 & 203 & $\mathrm{C}_{14} \mathrm{H}_{21} \mathrm{~N}$ & 34906103 & 10.510 \\
\hline 3 & 5-Ethyl-2-methyl-pyridin-4-amine & 10.328 & 136 & $\mathrm{C}_{8} \mathrm{H}_{12} \mathrm{~N}_{2}$ & 50212888 & 15.119 \\
\hline 4 & Limonene & 10.588 & 136 & $\mathrm{C}_{10} \mathrm{H}_{16}$ & 7755796 & 2.335 \\
\hline 5 & 2-(2-Hydroxyphenoxy) -1-phenylethanol & 10.855 & 230 & $\mathrm{C}_{14} \mathrm{H}_{14} \mathrm{O}_{3}$ & 8909854 & 2.683 \\
\hline 6 & Benzenemethanol, 3-hydroxy & 12.751 & 124 & $\mathrm{C}_{7} \mathrm{H}_{8} \mathrm{O}_{2}$ & 9255811 & 2.787 \\
\hline 7 & $\begin{array}{l}\text { 2,5-Cyclohexadiene-1,4-dione, 3-hydroxy-2- } \\
\text { methyl-5-(1-methylethyl) }\end{array}$ & 12.989 & 180 & $\mathrm{C}_{10} \mathrm{H}_{12} \mathrm{O}_{3}$ & 1919963 & 0.578 \\
\hline 8 & Succinic acid, di (but-3-yn-2-yl) ester & 13.094 & 222 & $\mathrm{C}_{12} \mathrm{H}_{14} \mathrm{O}_{4}$ & 17690896 & 5.327 \\
\hline 9 & 7-Methylenebicyclo [4.2.0] octane & 14.797 & 122 & $\mathrm{C}_{9} \mathrm{H}_{14}$ & 27572684 & 8.302 \\
\hline 10 & Cyclonon-4-ynone & 15.032 & 136 & $\mathrm{C}_{9} \mathrm{H}_{12} \mathrm{O}$ & 9330595 & 2.809 \\
\hline 11 & 3-Pyridinamine, $\mathrm{N}$-methyl-2-nitro & 15.325 & 153 & $\mathrm{C}_{6} \mathrm{H}_{7} \mathrm{~N}_{3} \mathrm{O}_{2}$ & 12194283 & 3.672 \\
\hline 12 & $\begin{array}{l}\text { 1,6,10-Dodecatriene, 7,11-dimethyl-3- } \\
\text { methylene }\end{array}$ & 15.565 & 204 & $\mathrm{C}_{15} \mathrm{H}_{24}$ & 12314843 & 3.708 \\
\hline 13 & $\begin{array}{l}\text { 2(5H)-Furanone, 4-methyl-3-(2-methyl-2- } \\
\text { propenyl) }\end{array}$ & 17.485 & 152 & $\mathrm{C}_{9} \mathrm{H}_{12} \mathrm{O}_{2}$ & 354536 & 0.107 \\
\hline 14 & $\begin{array}{l}\text { 7,12-Dihydro-6,7-bis(4-hydroxphenyl)-6H- } \\
\text { [1,2,4] triazolo [1,5,1,2] pyrimido [5,4-c] } \\
\text { chromen-2 o1 }\end{array}$ & 17.991 & 426 & $\mathrm{C}_{24} \mathrm{H}_{18} \mathrm{~N}_{4} \mathrm{O}_{4}$ & 801040 & 0.241 \\
\hline 15 & $\begin{array}{l}\text { 2,5-Cyclohexadiene 1,4-dione, 3-hydroxy-2- } \\
\text { methyl-5 (1-methylethyl) }\end{array}$ & 18.784 & 180 & $\mathrm{C}_{10} \mathrm{H}_{12} \mathrm{O}_{3}$ & 12400745 & 3.610 \\
\hline 16 & 9-Borabicyclo [3.3.1] nonane, 9-ethyl & 18.991 & 150 & $\mathrm{C}_{10} \mathrm{H}_{19} \mathrm{~B}$ & 27074161 & 8.152 \\
\hline 17 & $\begin{array}{l}\text { Spiro [2.2]pentane-1-carboxylic acid, 2- } \\
\text { cyclopropyl-2-methyl }\end{array}$ & 19.508 & 166 & $\mathrm{C}_{10} \mathrm{H}_{14} \mathrm{O}_{2}$ & 6402976 & 1.928 \\
\hline 18 & 1-Nitro-bicyclo [6.1.0] nonan-2-one & 20.257 & 183 & $\mathrm{C}_{9} \mathrm{H}_{13} \mathrm{NO}_{3}$ & 20237842 & 5.563 \\
\hline 19 & $\begin{array}{l}\text { 2H-1b,4-Ethanopentaleno [1,2-b]oxirene, } \\
\text { hexahydro-, (1a alpha, } 1 \mathrm{~b} \text {, beta, } 4 \text {, beta, } 4 \mathrm{a} \\
\text { alpha, 5a,alpha.) }\end{array}$ & 20.795 & 150 & $\mathrm{C}_{10} \mathrm{H}_{14} \mathrm{O}$ & 13878865 & 4.179 \\
\hline 20 & cis-beta-Farnesene & 21.465 & 204 & $\mathrm{C}_{15} \mathrm{H}_{24}$ & 287133 & 0.086 \\
\hline 21 & $\begin{array}{l}\text { 2H-Benzocyclohepten-2-one, } \\
3,4,4 \mathrm{a}, 5,6,7,8,9 \text {-octahydro-4a-methyl-(S) }\end{array}$ & 22.843 & 178 & $\mathrm{C}_{12} \mathrm{H}_{18} \mathrm{O}$ & 17407073 & 5.241 \\
\hline 22 & 2-(2-Furyl) pyridine & 24.200 & 154 & $\mathrm{C}_{9} \mathrm{H}_{7} \mathrm{NO}$ & 46846641 & 11.408 \\
\hline 23 & $\beta$-bisabolene & 24.413 & 204 & $\mathrm{C}_{15} \mathrm{H}_{24}$ & 17268013 & 4.036 \\
\hline 24 & Cyclohexene. 4-isopropenyl-1-methoxyme & 24.796 & 186 & $\mathrm{C}_{9} \mathrm{H}_{14} \mathrm{O}_{2} \mathrm{~S}$ & 16092684 & 4.845 \\
\hline 25 & $\begin{array}{l}\text { Naphthalene, } 1,2,3,4,4 \mathrm{a}, 5,6,8 \mathrm{a} \text {-octahydro- } \\
\text { 4a,8-dimethyl-2-(1-methylethenyl)-[2R-( } 2 \\
\text { alpha,4a alpha,8a beta)] }\end{array}$ & 28.268 & 204 & $\mathrm{C}_{15} \mathrm{H}_{24}$ & 11997604 & 2.727 \\
\hline 26 & Norcymserine,N-[2-phtenethyl] & 7.844 & 202 & $\mathrm{C}_{12} \mathrm{H}_{10} \mathrm{O}_{3}$ & 2687023 & 0.607 \\
\hline
\end{tabular}


Table 3. Chemical structures of the most prevalent compounds of ethyl acetate extract of stem of $A$. sowa:

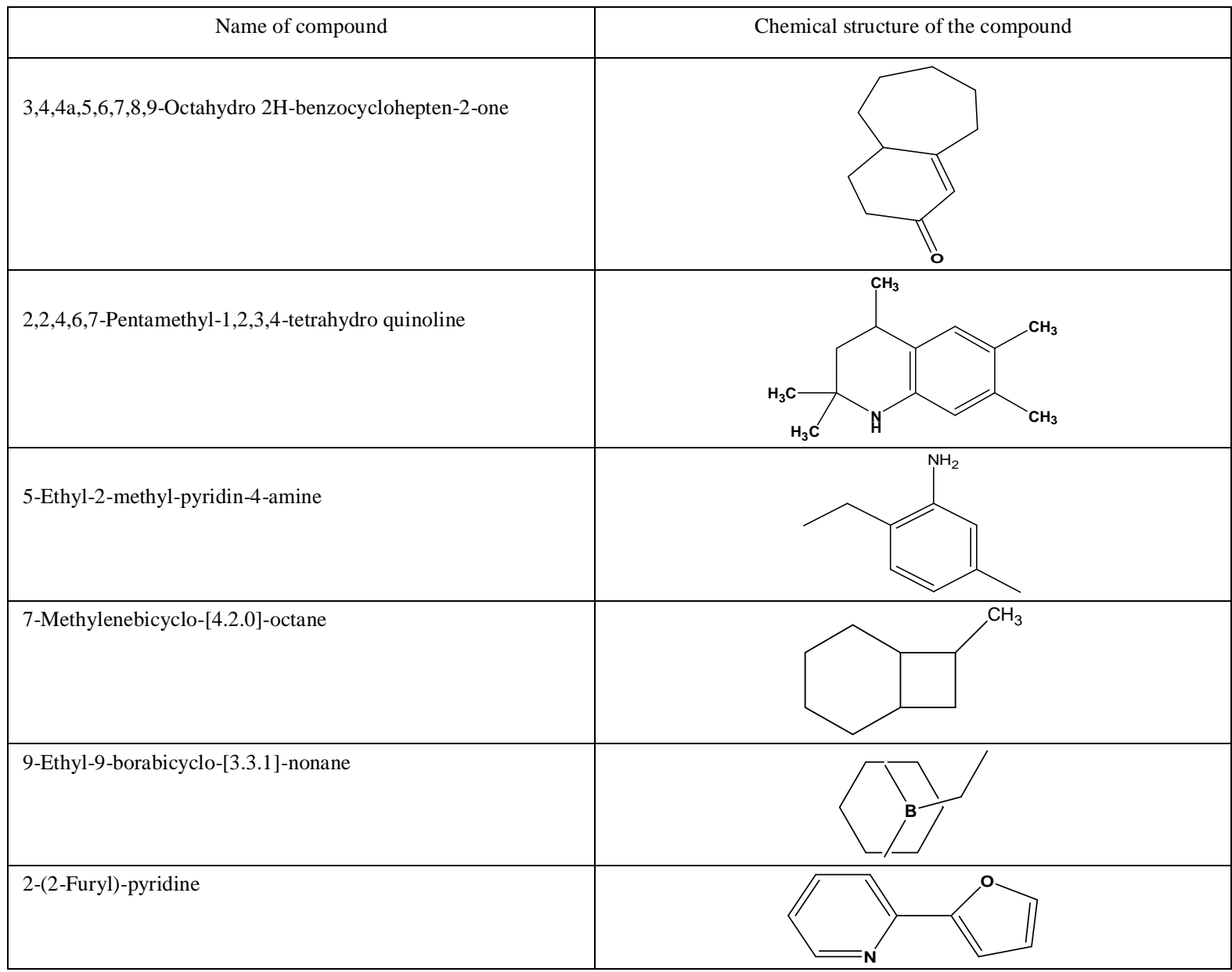

Table 4. Chemical constituents present in the ethyl acetate extract of seed using GC-MS analysis.

\begin{tabular}{|c|c|c|c|c|c|c|}
\hline No & Name of the Compound & R. time & $\begin{array}{l}\text { Molecular } \\
\text { weight }\end{array}$ & $\begin{array}{l}\text { Molecular } \\
\text { formula }\end{array}$ & Peak area & $\begin{array}{c}\text { Peak area } \\
(\%)\end{array}$ \\
\hline 1 & 3-Cyclopentyl-1-propyne & 6.149 & 108 & $\mathrm{C}_{8} \mathrm{H}_{12}$ & 45044690 & 14.137 \\
\hline 2 & 6-(2-Ethoxy-phenyl)-5 nitro-piperidin-2-one & 7.863 & 264 & $\mathrm{C}_{13} \mathrm{H}_{16} \mathrm{~N}_{2} \mathrm{O}_{4}$ & 2646183 & 0.824 \\
\hline 3 & Quinoline, 2,2,4,6,7-pentamethyl-1,2,3,4-tetrahydro & 8.668 & 203 & $\mathrm{C}_{14} \mathrm{H}_{21} \mathrm{~N}$ & 23328789 & 7.321 \\
\hline 4 & 5-Ethyl-2-methyl-pyridin-4-amine & 10.605 & 136 & $\mathrm{C}_{8} \mathrm{H}_{12} \mathrm{~N}_{2}$ & 4790942 & 1.504 \\
\hline 5 & 3-Pyridinamine, N-methyl-2-nitro & 10.605 & 153 & $\mathrm{C}_{6} \mathrm{H}_{7} \mathrm{~N}_{3} \mathrm{O}_{2}$ & 1902397 & 0.597 \\
\hline 6 & 5-Ethyl-2-methyl-pyridin-4-amine & 10.880 & 136 & $\mathrm{C}_{8} \mathrm{H}_{12} \mathrm{~N}_{2}$ & 5715519 & 1.794 \\
\hline 7 & 1-Methyl-2-trimethyloxycyclohexene & 13.107 & 198 & $\mathrm{C}_{11} \mathrm{H}_{22} \mathrm{OSi}$ & 10367603 & 3.254 \\
\hline 8 & $\begin{array}{l}\text { 2H-Benzocyclohepten-2-one, 3,4,4a,5,6,7,8,9- } \\
\text { octahydro }\end{array}$ & 14.800 & 164 & $\mathrm{C}_{11} \mathrm{H}_{16} \mathrm{O}$ & 38204660 & 11.990 \\
\hline 9 & 3-Pyridinamine, $\mathrm{N}$-methyl-2-nitro & 15.056 & 153 & $\mathrm{C}_{6} \mathrm{H}_{7} \mathrm{~N}_{3} \mathrm{O}_{2}$ & 4716306 & 1.480 \\
\hline 10 & 5-Decene, 4-ethynyl-, (E) & 15.344 & 164 & $\mathrm{C}_{12} \mathrm{H}_{20}$ & 6145828 & 1.929 \\
\hline 11 & $\begin{array}{l}\text { 2,5-Cyclohexadiene-1,4-dione, 3-hydroxy-2-methyl- } \\
\text { 5-(1-methylethyl) }\end{array}$ & 15.961 & 180 & $\mathrm{C}_{10} \mathrm{H}_{12} \mathrm{O}_{3}$ & 2714045 & 0.838 \\
\hline 12 & 1-Cyclohexene-1-methanol & 17.666 & 112 & $\mathrm{C}_{7} \mathrm{H}_{12} \mathrm{O}$ & 3918445 & 1.230 \\
\hline
\end{tabular}


Table contd.

\begin{tabular}{|c|c|c|c|c|c|c|}
\hline 13 & $\begin{array}{l}\text { Preg-4-en-3-one, 17. Alpha.-hydroxy-17. beta.- } \\
\text { cyano }\end{array}$ & 19.114 & 313 & $\mathrm{C}_{20} \mathrm{H}_{27} \mathrm{NO}_{2}$ & 134246 & 0.041 \\
\hline 14 & $\begin{array}{l}\text { 2H-Benzocyclohepten-2-one, 3,4,4a,5,6,7,8,9- } \\
\text { octahydro }\end{array}$ & 19.013 & 164 & $\mathrm{C}_{11} \mathrm{H}_{16} \mathrm{O}$ & 25824311 & 8.105 \\
\hline 15 & (1,3-Dimethyl-2-methylene-cyclopentyl)-methanol & 20.283 & 140 & $\mathrm{C}_{9} \mathrm{H}_{16} \mathrm{O}$ & 12875477 & 4.041 \\
\hline 16 & $\begin{array}{l}\text { 2H-Benzocyclohepten-2-one, 3,4,4a,5,6,7,8,9- } \\
\text { octahydro }\end{array}$ & 20.812 & 164 & $\mathrm{C}_{11} \mathrm{H}_{16} \mathrm{O}$ & 7849200 & 2.463 \\
\hline 17 & 9-Borabicyclo [3.3.1] nonane,9-ethyl- & 22.871 & 150 & $\mathrm{C}_{10} \mathrm{H}_{19} \mathrm{~B}$ & 12172867 & 3.820 \\
\hline 18 & Spiro [2.9]dodeca-4, 8-diene & 22.871 & 162 & $\mathrm{C}_{12} \mathrm{H}_{18}$ & 3109373 & 0.976 \\
\hline 19 & 1,5-Naphthyridin-2-amine & 24.192 & 145 & $\mathrm{C}_{8} \mathrm{H}_{7} \mathrm{~N}_{3}$ & 24220032 & 7.601 \\
\hline 20 & 2-Furanacetaldehyde, alpha-isopropylidene & 24.825 & 150 & $\mathrm{C}_{9} \mathrm{H}_{10} \mathrm{O}_{2}$ & 9834222 & 3.086 \\
\hline 21 & 4,7-Methano-5H-inden-5-one, octahydro & 25.296 & 150 & $\mathrm{C}_{10} \mathrm{H}_{14} \mathrm{O}$ & 78617338 & 24.673 \\
\hline 22 & $\begin{array}{l}\text { 2H-Benzocyclohepten-2-one, 3,4,4a, 5,6,7,8,9- } \\
\text { octahydro-4a-methyl-(S) }\end{array}$ & 26.387 & 164 & $\mathrm{C}_{11} \mathrm{H}_{16} \mathrm{O}$ & 2701114 & 0.826 \\
\hline 23 & $\begin{array}{l}\text { 2(1H)-Naphthalenone, 3,4,4a,5,8,8a-hexahydro-4a- } \\
\text { methyl-, trans }\end{array}$ & 28.281 & 164 & $\mathrm{C}_{11} \mathrm{H}_{16} \mathrm{O}$ & 19875495 & 5.733 \\
\hline
\end{tabular}

Table 5. Chemical structures of the most prevalent compounds of ethyl acetate extract of seed of $\mathrm{A}$. sowa.

\begin{tabular}{|c|c|}
\hline Name of compounds & Chemical structure of compounds \\
\hline 3-Cyclopentyl-1-propyne & \\
\hline 2,2,4,6,7-Pentamethyl-1,2,3,4-tetrahydro quinoline & \\
\hline $3,4,4 \mathrm{a}, 5,6,7,8,9$-Octahydro 2H-benzocyclohepten-2- & \\
\hline 1,5-Naphthyridin-2-amine & $\mathrm{H}_{2} \mathrm{~N}_{-}$ \\
\hline Octahydro-4,7-methano-5H-inden-5-one & \\
\hline
\end{tabular}

\section{CONCLUSION}

This study accentuates the presence of many secondary metabolites in the aerial parts of $A$. sowa as well as provides an overview of the different classes of molecules that may have pharmacological importance. So, further studies are needed on these 
phytochemical constituents in order to isolate and elucidate the structure of these compounds with different biological activities.

\section{ACKNOWLEDGEMENTS}

We are grateful to Institute of National Analytical Research and Services (INARS), BCSIR, Dhaka, Bangladesh for giving us the opportunity to use gas chromatography-mass spectrophotometer (GC-MS).

\section{REFERENCES}

1. Hosseinzadeh, S., Jafarikukhdan, A., Hosseini, A. and Armand, R. 2015. The application of medicinal plants in traditional and modern medicine: A review of Thymus vulgaris. Int. J. of Clin. Med. 6, 635-642.

2. Al-Mansur, M.A., Saha, K., Sultana, N. and Siddiqi, M.M.A. 2016. Comparative studies on cytotoxic, antibacterial and antioxidant activity among different extracts of seed and stem of Anethumsowa L. available in Bangladesh. World J. of Pharm. Res. 5, 01-10.

3. Harborne, J.B. 1973. Phytochemical methods. London chapman and hall, Ltd. Pp. 49-188.

4. Trease, G.E. and Evans, W.C. 1989. Pharmacognosy. 11th Edn. Brailliartiridel can. Macmillan publishers. p. 530.

5. Software, A. 1993. Medicinal plants and traditional medicines in Africa. Spectrum books ltd., Ibadan, Nigeria p. 289.

6. Adams, R.1995. Identification of essential oil components by gas chromatography/mass spectroscopy. Allured publishing Co., Carol Stream, II.

7. Vanden, D.H. and Kratz, P.D. 1963. A generalization of the retention index system including linear temperature programmed gas-liquid partition chromatography. $J$. Chromatogr. 11, 463-471.

8. Frantisek, S. 1991. The natural guide to medicinal herbs and plants. Twickenham, UK: Tiger bark institute. 1-8.

9. Irene, M.V., Mynthia, A.C. and Kenneth, B.M. 1998. Comparative antidiabetic activities of some medicinal plants. J. Ethnopharmacol. 22, 1-2.

10. Yu, Y.L., Leung, L.K. and Bi, Y.R. 2000. Antioxidant activity of flavonoids isolated from Scutellaria rehderiana. J. Am. Chem. Soc. 77, 807-813.
11. Clarke, E.G.C. 1975. Isolation and identification of drugs. Vol. 2. London, UK: pharmaceutical press; 905.

12. Finar, I.L. 1989. Organic chemistry: Stereochemistry and the chemistry of natural products. 5th ed. Singapore, Singapore: Longman Group; 517-605.

13. Anila, L., Vijayalakshmi, N.R. and Tian, C. 2000. Beneficial effect of flavonoids from Sesamumindicum, Emblica officinalis and Momordicacharantia. Phytother Res. 14, 592595.

14. Sui, D.Y., Luz, Z. and Li, S.H. 1994. Hypoglycaemic effect of saponins isolated from leaves of Acanthopanaxsenticosus. Int. J. Diab. Metabol..19, 683-685.

15. Ghislain, O., Sandra, L. and Nele, B. 2012. Applications of glycobiology: Biological and immunological effects of a chemically modified amylose-derivative. London, UK: RSC Publishing, 38.

16. Chakarborty, A., Choudhary, B.K. and Bhattacharya, P. 1995. Clausenol and clausenine - Two carbazole alkaloids from Clausena anisata. Phytochem.40, 295-298.

17. Boyce, P.W. and Christy L.P. 2004. Applied pharmacology for the veterinary technicians. 2nd ed. St. Luis, USA: WB Saunders Co. pp. 126-127.

18. Narayana, K.R., Reddy, M.R. and Chaluvadi-Krishna, D.R. 2001. Bioflavonoids classification, pharmacology, biochemical effects and therapeutic potential. Ind. J. Pharmacol. 33, 2-16.

19. Coleman, D.L. 1973. Effect of parabiosis of obese with diabetes and normal mice. Diabetologia. 9, 294-298.

20. Middleton, E.J.R., Kandaswami, C. and Theoharides, T.C. 2000. The effects of plants flavonoids on mammalian cells: Implications on inflammation, heart disease and cancer. Pharmacol. Rev. 52, 673-751.

21. Robak, J. and Marcinkiewiez, D. 1995. Scavenging of reactive oxygen species as the mechanism of drug action. $J$. Pharmacol.47, 89-98.

22. Parker, L., Rimbach, G. and Virgili, F. 1999. Antioxidant activity and biologic properties of a procyanidin-rich extract from pine (Pinusmaritima) bark pycnogenol. Free Rad. Biol. Med.27, 704-724.

23. Ahmad, M., Aktar, M.S. and Malik, T. 2000. Hypoglycemic action of the flavonoids fraction of cuminumseeds. Phytotherap Res.14, 103-106.

24. Ozçelik, B., Kartal, M. and Orhan, I. 2001. Cytotoxicity, antiviral and antimicrobial activities of alkaloids, flavonoids, and phenolic acids. Pharm. Biol. 49, 396-402. 